\title{
Use of Charitable Alms (Zakat) by Incumbent Candidates in Regional Elections in Indonesia (Two Case Studies) ${ }^{1}$
}

\author{
Zusiana Elly Triantini and Masnun ${ }^{2}$
}

Received: 25 July 2017 | Accepted: 12 March 2018 | Published: 26 March 2018

\begin{abstract}
This article seeks to expose incumbents' tendencies and strategies in using charitable alms (zakat) in regional elections in two areas. Strategies identified include determining binding regulations regarding the use of zakat money, as well as the positioning of persons considered loyal and strategic to incumbents within the leadership structures of zakat institutions. Meanwhile, incumbents worked to integrate and interconnect government programmes with local zakat distribution agencies and attracting public sympathies through the sharing of zakat funds. Incumbents benefit from their power and legitimacy, and can thus easily use zakat funds as an economic resource for gathering the support of zakat recipients (mustahiq $\left.{ }^{3}\right)$. With their power and legitimacy, incumbents are able to claim credit and thus enjoy greater popularity in their re-election campaigns. This power and legitimacy, as well as its benefits, are managed strategically and intelligently to avoid giving the impression of illegality and ease social acceptance. The findings of this research are opposite to those of Samantha May; where May has found that state dominance and control of zakat has met widespread resistance, this research has found that state dominance and control of zakat has not only been well-received by society, but has also had implications for politicians' role in zakat management and distribution. This research, conducted through observation and interviews with zakat distributors / recipients, indicates how clientelism is formed through the government zakat distribution agency (Badan Amil Zakat, 'Zakat Distribution Agency'), the structural/instrumental approaches used by incumbents, and the response of zakat recipients. This article takes two elections in two regions as case studies: Kulon Progo in the 2017 regional election and Magelang Regency in the 2013 regional election.
\end{abstract}

Keywords: Patronage, clientelism, incumbents, zakat, charity, strategies, regional elections

1 This research was funded by the Local Election Research Project together with the Research Centre for Politics and Government (PolGov), Universitas Gadjah Mada, and the Australian National University.

2 Zusiana Elly Triantini is a lecturer at the Faculty of Law and Sharia at the Sunan Kalijaga State Islamic University, Yogyakarta, and Masnun is a lecturer at the Postgraduate Programme of the Mataram State Islamic University, West Nusa Tenggara.

3 Eight groups are identified as mustahiq zakat: fakir (the poor), miskin (the needy), amil (zakat collectors), sabilillah (persons fighting for God), ibnu sabil (stranded travellers), gharim (persons overwhelmed by debt), mualaf (converts), hamba sahaya (persons to be freed from slavery). 


\section{Introduction}

In 2012, a national meeting and conference of Alim Ulama and Nahdlatul Ulama was held at the Kempek Islamic Boarding School in Cirebon, West Java, from 15 to 17 September to discuss a fatwa (edict) regarding money politics in the form of charity and alms (sedekah and zakat). This fatwa was passed in recognition of the common framing of money politics as sedekah and zakat, which thus directly and indirectly linked the two to political interests and affected voters' choices. Nahdlatul Ulama, the largest religious organisation in Indonesia, emphasised that open money politics was riswah (bribery), and therefore both giving and receiving money was considered haram (prohibited); consequently, voting for a candidate who distributed money to voters was likewise considered haram. Meanwhile, where a recipient did not truly understand that zakat, sedekah, or other financial assistance was given to influence voting, the practice was considered haram for the person giving money but mubah (permitted) for the recipient (Wahid \& Alim, 2016).

The Nahdlatul Ulama's examination of this issues was very urgent, as money politics has long been practiced in Indonesia, where government leaders have positioned themselves as "generous benefactors" to gain significant political capital in the form of public support and votes. Being "charitable" by giving zakat and sedekah has been the rational choice for politicians seeking the support of the public, particularly the poor.

Candidates have thus been driven to use various strategies to ease access to voters and votes, as well as to guarantee the greatest loyalty from their supporters through activities such as establishing financial institutions as engines of party "charity" (Latief, 2013) and using zakat distribution agencies to provide patronage to voters. ${ }^{4}$ This is a "safe" strategy, as there has yet to be any legal cases regarding

4 Individual research conducted by Zusiana Elly Triantini and Emmy Hartatik et al. regarding the effectiveness of zakat programmes in overcoming poverty in Central Java, East Java, and the Special Administrative Region of Yogyakarta. 
the use of zakat money for political capital / money politics, despite zakat being legally required to remain neutral in politics. In this context, voters have a weak position, as they are expected only to do as expected by those in power. Furthermore, the legitimacy of their power enables incumbents to freely use zakat money for their populist programmes.

History has shown that the practice of money politics has been seemingly unending in Indonesian. Research in money politics in Indonesia conducted by the Research Centre for Politics and Government (PolGov) at Universitas Gadjah Mada in conjunction with the Australian National University (Aspinall \& Sukmajati, 2015) even found an increase in the practice of money politics in recent years, with the 2014 legislative election being the "worst" in the history of procedural democracy in Indonesia. Jimly Assidiqie, the Head of the Honorary Board for Elections, described the practice of money politics in the 2014 elections as the most 'massive' in Indonesian history (Jimly: Politik, 2014).

Research indicates that money politics has been widespread in almost every Indonesian election. In elections in 2013, 2014, 2015, and 2017, pork barrel politics, vote buying, club goods, and programmatic politics were rampant. The politics of "charity", however, has been relatively new, emerging only in the 2013 and 2017 regional elections. Philanthropic institutions, such as the governmentrun Badan Amil Zakat (Zakat Distribution Agency, LAZ), were used by candidates for patronage purposes in campaigning and collecting votes. Exploiting various legal opportunities as well as their autonomous authority in managing zakat and synergising it with government programmes, incumbents in Magelang and Kulon Progo were able to successfully seek re-election. These two cases offer empirical proof of the use of zakat money as political capital, as identified by the above-mentioned meeting of the Alim Ulama and Nahdlatul Ulama.

Zakat distribution agencies, which according to Islamic teachings should ideally be basis for poverty eradication, have 
been mobilised for political purposes by incumbents in various parts of Indonesia, thereby tainting the professionalism of these agencies, which should abstain from politics. The charitable goals of zakat distribution agencies are seemingly forgotten. Meanwhile regulations that threaten persons misusing zakat distribution with fines of up to $\mathrm{Rp} 500$ million and five years' imprisonment ${ }^{5}$ are insufficient to prevent irregularities in zakat distribution. Zakat distribution agencies are thus used as political brokers, with their distribution of zakat being used to promote incumbents' political interests.

\section{Political Aspects of Zakat Management and Distribution in Indonesia}

Investigation of the connections between politics and zakat distribution agencies (in this case, the state-run Badan Amil Zakat) can begin with discussion of the history of zakat management and distribution in Indonesia. History shows that tendencies in these connections have tended to change in different eras. During the colonial era, management of zakat was entrusted to communities. The colonial state avoided interfering in such affairs. As Islamic boarding schools, madrasahs, and Islamic civil society organisations developed within society, so did zakat and sadaqah.

According to Snouck Hurgronje, the payment of zakat and sedekah during the colonial era was voluntary, involving patronclient relations between zakat recipients and ulama (Islamic scholars), penghulu (officiants), prayer teachers, and midwives. As such, influence and social loyalty was granted to local religious leaders and teachers, what Fauzia terms the remuneration of patron-client relations or repayment of service. However, in a fatwa presented by Niko Kaptein in Muhimmat al Nafa'is, it is stated that in 1892 there were cases of zakat and sedekah being forcefully collected and used by rulers to construct enormous homes and mosques, and to pay religious teachers and figures (Fauzia, 2016).

Articles 39 and 40 of Law No. 23 of 2011 about Zakat Management (Ind). 
In the Old Order, the state only provided supervision for the distribution of zakat. Decree of the Minister of Religion No.A/ VII/17367 of 1951 continued the Dutch policy of avoiding state interference in zakat collection and distribution. Instead, in stipulated that the state would only supervise the administration of zakat and monitor its distribution.

Only in the New Order did the government become directly involved in the management and distribution of zakat. In 1964, for example, the Ministry of Religion prepared a draft law on zakat, while a planned government regulation (to replace a law) was prepared for zakat collection and distribution, as well as the establishment of baitul mal (financial institutions). However, neither of these reached the Indonesian Parliament or President before the end of the Old Order. Only in 1967 was concrete action undertaken, when the Ministry of Religion sent a draft law on zakat to parliament. At the time, the Ministry argued that the payment of zakat was expected of Indonesia's Muslims, and that the state thus had a moral obligation to administer it (Effendy, 1998).

One year later, based on the recommendations and input received from various parties, the Ministry of Religion issued Decree of the Minister of Religion No. 4 of 1968 regarding the Establishment of the Badan Amil Zakat, to store collected zakat funds, as well as Decree of the Minister of Religion No. 5 of 1968 regarding the Establishment of Baitul Mal, an organisation established to collect zakat. However, both decrees were soon repealed, as the Ministry of Finance rejected the planned zakat legislation, despite the fact that this ministry had previously argued that a ministerial decree was sufficient for $z a k a t$ administration.

However, at the urgings of the president, in commemoration of the Isra Mi'raj and Eid al-Fitr, Instruction of the Minister of Religion No. 1 of 1969 regarding the Postponement of the Implementation of Decree of the Minister of Religion No. 4 and 5 of 1968 was issued. President Soeharto emphasised the need for systematic zakat management (ibid). 
After this postponement was announced, the state's involvement in zakat management stagnated. In this context, zakatdespite its potential to promote economic development-had a limited and primarily cultural function. Zakat was only distributed through religious institutions such as Islamic boarding schools, orphanages, or community organised zakat agencies. However, these were primarily temporary, and they managed only zakat fitrah (compulsory alms), rather than zakat maal (alms from wealth).

New breath was given to zakat management in the 1990s, when the state began to focus on zakat management through its new Badan Amil Zakat, Infaq dan Shadaqah (Agency for the Distribution of Alms, Donations, and Charity; BAZIS). In 1991, the government issued Joint Decree of the Minister of Domestic Affairs and the Minister of Religion No. 29 and 47 of 1991 regarding the Badan Amil Zakat, Infaq dan Shadaqah. This was followed by Instruction of the Minister of Religion No. 5 of 1991 regarding Technical Guidance for the Badan Amil Zakat, Infaq, dan Shadaqah and Instruction of the Minister of Religion No. 7 of 1998 regarding the General Guidance of the Badan Amil Zakat, Infaq, dan Shadaqah. This was influenced strongly by the thawing relations between the state and Islamic organisations such as Muhammadiyah and Nahdlatul Ulama, which were also involved in the management and distribution of zakat. This agency existed together with community organisations such as LAZ.

The management of zakat money continued to develop dynamically together with the political and economic conditions in Indonesia. This peaked in 1999 with the passing of Law No. 38 of 1999 regarding Alms Management, following by Decree of the Minister of Religion No. 581 of 1999. These regulations were revised through Law No. 23 of 2011 regarding Alms Management and Government Regulation No. 14 of 2014 regarding the Elucidation of Law No. 23 of 2011.

A number of clauses in these new regulations on the management of zakat have been exploited to create structured 
patron-client relations. For instance, Article 34, Paragraph 2 of Law No. 23 of 2011 stipulates that "The Governor and Regent/Mayor guides and supervises the provincial and regency/ municipal and LAZ per their authority". ${ }^{6}$ Meanwhile, Article 41, Paragraph 5 and 6 of Government Regulation No. 14 of 2014 stipulates that "The administrator, as intended in Paragraph (1), should not be a civil servant", 7 but "where necessary the administrator may be a civil servant given as assistance". ${ }^{8}$ Furthermore, Article 41, Paragraph 1 , states that the leadership of Baznas "is to be appointed and dismissed by the regent/mayor upon consideration of Baznas". ${ }^{9}$ From this discussion, it is apparent that regulations regarding zakat management have enabled patron-client relations to be created relatively easily between incumbents (regents/mayors) with the leadership and administration of Baznas, as found in Magelang and Kulon Progro, where the leaders of the zakat distribution agencies chosen by incumbents were those close to them, such as the regional secretary or deputy regent. These people thus gained considerable authority in determining the agencies' programmes.

In response to the above regulations, several regional leaders in began to draft and pass regional by laws on zakat collection for both state- and private-sector employees the employees, while other regencies passed similar regulations through instructions or recommendations that civil servants and private-sector employees pay 2.5 percent of their wages as zakat, with Muslims not meeting the requirements for compulsory zakat instructed/recommended to donate money. Research by Michael Buehler (2008) made similar findings in Barru, Bulukumba, South Sulawesi, as well as West Java,

Original: Gubernur dan Bupati/Walikota melaksanakan pembinaan dan pengawasan terhadap Baznas Provinsi dan Baznas kabupaten/kota, dan LAZ sesuai dengan kewenangannya.

7 Original: Pelaksana yang dimaksud ayat (1) berasal dari bukan pegawai negeri sipil" namun ayat selanjutnya menyebut.

8 Original: Dalam hal diperlukan, pelaksana dapat berasal dari pegawai negeri sipil yang diperbantukan.

9 Original: ... diangkat dan diberhentikan oleh Bupati/ walikota setelah mendapatkan pertimbangan Baznas. 
Banten, Central Java, East Java, Riau, South Kalimantan, East Kalimantan, West Sumatra, and Aceh. ${ }^{10}$

This popular concept was also applied in other regions such as Magelang and Kulon Progo, where this research was conducted. In both of these research locations, the regency governments issued recommendations for optimising zakat collection, in Magelang in 2009 and in Kulon Progo in 2012. This appears to have been a useful strategy for collecting zakat. Before these recommendations were passed, the collection of zakat by the local Baznas offices was minimal. For example, in Magelang, a total of Rp. 132,000,000 was collected in 2008; five years later, in 2013, Rp. 947,000,000 was collected - an average of Rp. 78,000,000 per month (EH, interview, November 13, 2015). Much of this money was collected from the different amounts of zakat paid by civil servants in Magelang, as suited for their station: section chiefs Rp 50,000 per month; subsection chiefs Rp 40,000 per month; Level III staff Rp 15,000 per month; and Level II staff Rp. 10,000 (Jawa Pos Radar Kedu, 2016).

Likewise, in Kulon Progo, where Rp. 2,000,000 to Rp. 13.000.000 in zakat was collected per annum before 2010, after the recommendation was made zakat collection increased drastically, reaching Rp. 130,000,000 per month, with 99\% being collected from civil servants and $1 \%$ being collected from individuals. In June, when civil servants received their 'thirteenth salary', zakat collection reached Rp. 234,000,000 (JM, interview, January 18, 2017).

The zakat funds collected ultimately became a major "alternative" source of money for incumbents in Kulon Progo and Magelang to collect votes through different binding and semibinding variations. In Kulon Progo, this was realised by integrating government programmes with those of the zakat collection agency. During the distribution of zakat funds, the incumbent became directly involved in giving the money to recipients, the amount having been determined based on proposals submitted by each

10 Each regional government's website, 2016. 
district. Meanwhile, in Magelang, zakat money was distributed to the incumbent's supporters directly, either before or during elections.

\section{Research Design and Methodology}

Several studies have examined the connection between zakat and politics. In "Political Piety: The Politicization of Zakat", Samantha May (2013) argued that, as a social transfer system, zakat serves to connect Muslims with people around the world, although this practice cannot truly be viewed through globalisation theory. In this article, May investigated zakat management in Malaysia, Egypt, and Palestine, focusing particularly on the nationalisation of zakat distribution in these countries and its effects on public trust in the zakat institutions managed by the state and by the private sector. Amelia Fauzia (2016) examined the history of Islamic philanthropy within the contestations of state and civil society in Indonesia, from the colonial era until 2010. Meanwhile, Hilman Latief (2013) wrote about the context of the politics of charity exhibited by the charitable organisations established by such political parties as the Partai Keadilan Sejahtera (Prosperous Justice Party; PKS), Partai Demokrasi Indonesia Perjuangan (Indonesian Democratic Party of Struggle; PDIP), and Golongan Karya (Functional Groups Party; Golkar) to garner the sympathies of their constituents. Meanwhile, Buehler (ibid) clearly wrote the results of his research in "The Rise of Shari'a by Law in Indonesian Districts", which investigated the political interests behind the sharia regulations of several regional governments in Indonesia, some of which deal with zakat as part of Islamic law.

Research to date has yet to investigate the clientelistic structures and strategies behind zakat collection and distribution, including the programmatic political model used to collect votes. Revelation of the structures being developed, the identities of those involved (such as brokers), and the legal constructions are quite important. Aside from examining the above question, this article will also compare 
the strategies used in two different places and their influence on the votes received by incumbents; this endeavour is necessary to fill the gap in current literature on politics and zakat.

Mapped systematically, this research will investigate three things. First, the structural context, i.e. the structures that enable the programmatic use of zakat in politics by incumbents, which has been very effective within existing economic and political systems. This is intended to identify operators and brokers. Second, it will examine the instruments used to ensure the successful use of zakat funds, including the total value of assistance, populist elements, and programmatic political choices (public goods, club good, private goods). Third, this article will examine the relations between incumbents and voters, particularly the assistance provided by incumbents from zakat funds. These three aspects jointly shape how incumbents' use populistic programmes in their search for electoral victory.

To collect more data on structural patterns, patronage patterns, and relations between incumbents and voters, the researcher conducted interviews with the leaders of the BAZ, zakat distribution division, and zakat collection division of each regency. Furthermore, the researcher conducted interviews with zakat recipients, particularly those who received zakat through integrated regional government programmes, based on data collected by each BAZ.

Within the government, the researcher conducted interviews with village chiefs and Rukun Tetangga (neighbourhood, RT) leaders as those connecting zakat recipients and the BAZ through programmes created by the regional government. The researcher also interviewed government officials who served as zakat collectors. For additional information, the researcher also conducted interviews with members of the elections' commission and administrators of zakat distribution agencies operated by religious organisations.

This article offers an understanding of various elements behind the rise of patron-client relations in two regencies, namely Magelang 
and Kulon Progo. Significant differences exist in the patron-client relations as found in Magelang Regency and Kulon Progo Regency, influenced by several points: first, the economic conditions of target communities, with significant differences between urban and rural areas; second, legal loopholes; third, political networks. The patronclient relations between Baznas and incumbents (mayor and deputy mayor) in Yogyakarta are not apparent, or at least unclear. In fact, Baznas officials stated that there were clear boundaries between the agency and government, including in their collaborative projects, which are presented as intended solely to collect data on people in need of zakat. This sort of collaboration also involves programme reporting and guidance (DN, interview, January 18, 2017).

This is far removed from the findings in Magelang and Kulon Progo, where patronage and clientelism are clearly evident in the programmatic politics that offer a "reliable alternative" for incumbents in Magelang and Kulon Progo.

\section{Zakat in Regional Elections: The Cases in Two Areas}

One important point that requires consideration before discussing patterns of clientelism and patronage in Magelang and Kulon Progo is the demographic situation in each regency. This data shows that practices in these regencies is adapted to various factors, particularly religious and economic ones.

Census data indicates that, in the two regencies where research was conducted, the majority of residents are Muslim. In Magelang, $96 \%$ of the population is Muslim, whereas in Kulon Progo $94 \%$ of the population is Muslim. These percentages, of course, have implications for the collection and distribution of zakat by incumbents with their varied tendencies and strategies. Aside from religious factors, another point that must be considered is the source of livelihood among recipients of zakat money. In Magelang, the vast majority of the population works in agriculture $(50 \%)$, followed by industry (21\%); the remainder works in services, trade, 
etc. The situation in Kulon Progo is similar to that in Magelang. Agriculture is the main source livelihood (50\%), followed by trade $(16 \%)$, industry $(12.7 \%)$, and the remainder are involved in the service sector (www.bps.go.id).

This demographic situation, both as related to religion and livelihood, gave local governments (incumbents) opportunities for their programmes, and had implications for their use of such "charitable" organizations as Baznas. In fact, in both Magelang and Kulon Progo, the use of zakat money through Baznas was systematic and exhibited considerable collaboration.

In 2013, Magelang held its regional elections. This election was contested by HMZ, who had served as deputy regent of Magelang from 2008 to 2013 and the head of the local zakat distribution agency (also from 2008 to 2013). In 2013, HMZ emerged victorious when he ran together with ZA; again he took leadership of the zakat distribution agency. It was this structural position that enabled the incumbent to use zakat money as an alternative to public funds in seeking public support. The incumbent, i.e. the deputy regent, used zakat money as political capital. This money was entirely within the full control of the incumbent, and as such the distribution of zakat and selection of recipients was used to seek voter support. The incumbent made a political promise to provide assistance to supporters if they filed a proposal for productive zakat. No specific amount was specified, although many were valued at between

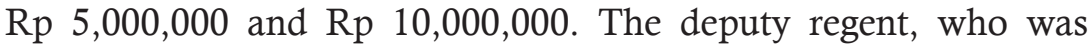
backed by PDIP, also used zakat funds to print campaign banners (PB, interview, November 13, 2015). Zakat was also used for other programmes meant to provide equipment to farmers. The incumbent used both pre-paid and post-paid zakat distribution models for his patronage. The pre-paid model was evident in assistance programmes that were consumptive or direct in nature, such as the provision of equipment to farmers, the provision of money (between $\mathrm{Rp} 100,000$ and $\mathrm{Rp} 250,000)$ to madrasah teachers and prayer teachers, and the construction of mosques (amounts varied). This was distributed 
directly by the incumbent, before the election, with the promise that more would be available if the incumbent were elected. Meanwhile, the post-paid model mostly took the form of programmatic politics using a transactional model. Those who provided support to the incumbent could submit a proposal to the incumbent for productive financial aid, which would later be paid from zakat money (PB, ibid; $\mathrm{EH}$, ibid). The amount of aid given would be determined by the

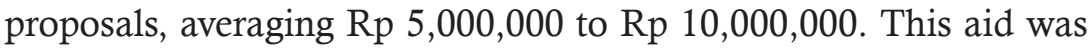
labelled "productive zakat assistance".

In 2017, the political stage in Kulon Progo was taken over by two pairs of candidates. The first pair were $\mathrm{Z}$ and I, with I being descended from the Pakualaman family of Yogyakarta), while the second pair were $\mathrm{H}-\mathrm{T}$ (previous regent of Kulon Progo). One frequent argument made by the first pair of candidates was related to the use of zakat money in promoting the Kulon Progo government's programmes in the previous term. One controversial issue was the regent's recommendation that all civil servants and privatesector employees pay zakat or sodaqoh, with $2.5 \%, 2 \%, 1.5 \%$, or $1 \%$ being garnished directly from their wages. Although the principle of sacrifice was emphasised by the incumbent, this policy drew support and criticism from local residents. Zakat distribution was integrated with government programmes, without zakat recipients being told that the money they were receiving came from zakat. Rather, recipients considered the money to be from the government coffers, as it was integrated into the programmes of the regional government.

Several zakat recipients stated that they received money from $\mathrm{H}$ (the incumbent) without knowing its origins. For example, one recipient of housing aid from Bumirejo, Lendah, Kulon Progo, stated "I didn't know the assistance came from the government. I thought it came from the government. But it has to continue, because the terrace is not finished" (SM, interview, February 8, 2017). Another informant, from Tirtorahayu, Galur, Kulon Progo, stated "I didn't know, because as far as I knew I collected 
the money from the Ministry of Religion with the village chief" (SYD, interview, February 11, 2017). ${ }^{11}$ The various statements made by informants indicated that this money was believed to originate from the government, despite that money originating from zakat money collected based on the incumbent's recommendation. It is clear that the use of zakat money (as if it were public money) was hidden behind legislation, so that it would not be illegal, even as that money was used to support the incumbent's programmes (Schedler \& Schaffer, 2007).

In Kulon Progo, zakat money was used for populist programmes such as Bedah Rumah (Housing Assistance). Every month, Baznas provided financial assistance of Rp 10,000,000 to three or four households in Kulon Progo. Money was also allocated for mosque construction, with the amount being determined by the amount requested in the proposal filed with the government. Every month, Baznas funded four mosques. Often accompanying this financial assistance was entrepreneurial aid for the local poor (in the

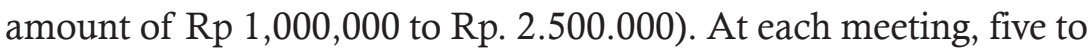
ten assistance packages would be provided in the form of grants, the returning of which from recipients' business profits was not required. Other programmes were the provision of financial assistance of Rp. 750,000 to university students writing their undergraduate theses, following an individual proposal model; financial assistance of Rp 150,000 to senior high school students, following a school proposal model; and the provision of bequests (bisaroh) of Rp 100,000 to the teachers of children's Qur'anic reading groups. There was also nonroutine assistance provided to the victims of natural disasters and the subsidising of healthcare costs.

In some programmes, zakat was distributed jointly, such as in the Ministry of Religion office, the regency pendopo (traditional house), the mosque (through 'Friday safaris'), and other strategic

11 Original: mboten ngertos karena ngertose nggeh ken mendet arto sareng Pak kades wonten kantor kemenag. 
locations. Some recipients of housing aid held ceremonies upon their homes' completion, to which the incumbent would come and formally open the house, witnessed by local residents (JM, interview, January, 18, 2017; AKH, interview, January 19, 2017). In the 2017 election, the incumbent won $84 \%$ of votes.

Zakat money was used as political capital by incumbents in Magelang and Kulon Progo through populist programmes that seemed to promote the interests of the community. Similar patterns being used to reach Muslim groups, such as the provision of bisaroh to prayer teachers and repairing mosques, reinforced the view that the incumbent gave special attention to religious communities, which in turn suggested that the incumbents were very pious. In Kulon Progo, religious slogans such as "don't forget to use your home to worship Allah" reinforced this perceived emphasis of religious aspects. This research found that such populist programmes using zakat money were most easily implemented in areas where most residents are rural farmers, i.e. such as Magelang and Kulon Progo. This finding indicates that economic factors can be used to judge the potential for zakat money to be used by incumbents. Demographically, both Kulon Progo and Magelang are areas with high poverty rates. Furthermore, levels of education and knowledge of the means and requirements for accessing zakat money have also promoted their willingness to accept zakat money, even when incumbents' political interests are behind its distribution.

\section{Developing Clientelism and Patronage: The Use of Zakat Money}

The regional Baznas are extensions of the national Baznas located in Jakarta. As such, the programmes implemented by these local agencies must be compatible with those at the national level. However, in practice the regional Baznas have considerable freedom in determining their own programmes, based on the argument that these agencies best know the needs of the communities in their area. This condition has been exploited by incumbents in Magelang and 
Kulon Progo to collect voters' support.

\section{Structural Design}

The incumbents in this research, i.e. the deputy regent of Magelang and regent of Kulon Progo, held considerable authority at the regency level. They had the authority to prepare programmes and budgets and apply them in local society. Furthermore, the incumbents had the authority to address problems through the various elements of the bureaucracy. With this authority, incumbents thus enjoyed access to more resources than their opponents.

The opportunities granted to incumbents to monopolise power appear to have been used strategically by incumbents in both Magelang and Kulon Progo. The Baznas in Magelang was headed by the incumbent himself, then deputy regent, while in Kulon Progo the agency was headed by a civil servant (i.e. the regional secretary of Kulon Progo) with close structural proximity to the incumbent.

In the case of Magelang, as the deputy regent had the authority to manage and distribute zakat money, the incumbent had full authority to determine zakat programmes - up to and including using zakat money for the purpose of printing campaign banners and other materials. The incumbent (HMZ) utilised a single actor model, and thus he alone had the ability to determine programmes and programme recipients as well as the use of zakat money. The staff working at the regional Baznas worked solely as administrators, handling the everyday documentation and administrative activities necessary for collecting and distributing zakat money ( $\mathrm{EH}, i b i d)$.

In the case of Kulon Progo, as the regional secretary and head of the local Baznas, JM could easily coordinate with the incumbent in the collection and distribution of zakat money. JM said in the mass media that "during the elections there would be no distribution of zakat". ${ }^{12}$ However, in practice, the distribution of zakat money continued throughout the campaign, something that was cited as

12 Original: "Selama masa pilkada tidak ada pentasyarufan zakat". 
being intended to finish earlier programmes before the change in leadership. Financial assistance for the renovation of mosques, as well as business assistance for local residents, was distributed every Friday. Although the incumbent did not attend the distribution ceremonies, the money was given directly by the head of the local Baznas (JM, ibid).

\section{Between Club Goods and Public Goods, Pre-Paid and Post-Paid}

Similar tendencies could be found in the use of zakat money for political capital by incumbents in Magelang and Kulon Progo. Both began by recommending that all civil servants and privatesector employees pay zakat, then continued by positioning allies in positions of power over the collection and distribution of zakat. However, these two regions had different tendencies in their distribution of zakat.

In Magelang, Baznas - fully under the authority of the incumbent-had numerous programmes that were rooted in the recognised opportunities for using zakat money. The distribution of zakat to various Muslim groups in Magelang, as well as religious leaders and party supporters, was paramount to the incumbent's strategy. In this "club good" model, the incumbent used several mechanisms to mitigate observers' impressions of manipulation. The incumbent directly gave assistance to selected groups and provided them with political recommendations. This was intended to ensure the incumbent was elected.

Another model was the "public good" model. Farmers, for example, received farming equipment, fertiliser, as well as staple goods. This type of populist programme was used by the incumbent to draw the sympathies of voters.

Interestingly, the incumbent in Magelang used both "prepaid" and "post-paid" strategies (the researcher's own terms). The pre-paid strategy was used to distribute zakat in the form of consumptive goods, both to promote club good and to promote 
public good, including assistance and equipment to farmers and farm labourers, bisaroh to prayer and madrasah teachers, as well as stable goods to the poor. This distribution of zakat was conducted before the election, and the total amount distributed was no more than Rp 1 million per person. Meanwhile, the post-paid strategy was used for the distribution of productive forms of zakat such as business assistance. This assistance was only given to recipients after the election. This political promise tended to be made during the campaign and limited to supporters of the backing party (i.e. PDIP) (EH, ibid).

Somewhat differently, in Kulon Progo the coordination between Baznas and the government was realised through, for example, the planning of the agency's programmes. Both "club good" and "public good" strategies were used. The "club good" approach was used, for example, in the mosque refurbishing programme, as well as the use of zakat money to provide entrepreneurial assistance to residents of certain villages. In this context, only those classified as mustahiq (having the right to receive zakat) could benefit from government programmes using zakat money. Those not classified as mustahiq could not access this financial assistance. The "public good" approach was also used to draw the sympathies of voters. In Kulon Progo, this was manifested (for example) through housing assistance, healthcare assistance, and scholarship programmes, as well as financial assistance for Qur'anic reading teachers.

In several studies of money politics, the public good has frequently been positioned as "weak" and "non-binding" because its benefits could be obtained without any firm political commitment from recipients (Stokes, 2007; see also Djani, 2013). However, in the Kulon Progo regional election, the public good was capable of drawing the sympathies of voters, who received the impression that the politics practiced were "clean" and "not corrupt". This narrative of clean and non-corrupt politics was evident in several interviews. Several respondents made statements such as "these programmes were useful for everyone (non-discriminative), and he was clean (not 
corrupt)" (SD, interview, February 3, 2017). ${ }^{13}$

Another point that indicates the strength of the public good can be found in the way that programmes from the government (i.e. incumbent) made use of zakat money. According to the cultural construct of "repaying favours" found throughout Yogyakarta, including Kulon Progo recipients had a moral obligation to those who provided them with assistance; this benefited the incumbent.

The above discussion of the instruments and strategies used in these two regencies illustrate the various approaches and strategies used by incumbents to transform zakat money into political capital and thereby garnish the sympathy (and votes) of beneficiaries. This, thus, was hoped to ensure electoral victory.

\section{The Effectiveness of Zakat Use for Collecting Voter Support}

Several research projects have shown that public funds (such as national or regional budgets) have been used for public programmes as a means of collecting votes. This is similar to the use of zakat, as this socio-religious source of funding, managed by the government, was also used to collected votes, even though the amount collected was relatively limited in number. Ultimately, zakat money was used by incumbents in Kulon Progo and Magelang to minimise the need to "buy votes" with their own money. Furthermore, they manipulated the provision of financial assistance to constituents, positioning this money as if it originated from the government when in actuality this money was compulsorily collected as zakat payment by government-run agencies in Kulon Progo and Magelang.

In practice, the distribution of zakat money contributed some votes in the 2013 and 2017 regional elections, albeit with different tendencies in each regency. The incumbent in Magelang relied primarily on clientelist relations, with zakat being distributed to persons considered to be within the party network, including party

13 Original: nggeh sae, kagungan program yang manfaat untuk semua (non-diskriminatif) dan beliau bersih (tidak korupsi). 
cadres and supporters. With the post-paid proposal mechanism, the messages of the incumbent were conveyed, directly or through party brokers, to zakat recipients $(\mathrm{EH}$, ibid). Meanwhile, the desire to attract votes was implicit in the various activities through which zakat money was distributed, both to farmers' groups and religious figures (prayer teachers, Islamic scholars) ( $\mathrm{PB}$, ibid).

This is different than in Kulon Progo, where the incumbent was not recorded as giving verbal instructions to aid recipients or urging them to vote for him in the 2017 election. However, the narrative of "repaying favours" (compensating) was presented by several informants who had received financial or housing assistance from the zakat agency of Kulon Progo, who sought to repay their debt of honour to the incumbent. This narrative of compensation offers an important point, namely that cultural patterns and characteristics within a society determine the types of communications used for patronage and clientelism.

Of eight zakat recipients interviewed, seven stated they would support the incumbent. When asked whether they would vote for the incumbent in the regional election, having received zakat money in the form of housing assistance (although, in this case, the informant did not know that the money originated from zakat), answers included "Yes, generally... we'd already built it here, so we'd vote for him"(SYD, ibid) and "if he were good, generally we voted for him because he provided us with infrastructure and facilities; people around here mostly voted for $P a k \mathrm{H}$, as he was good and not corrupt. ${ }^{14}$ The phrase "generally" was intended by the informant to refer to the politics of "repaying favours". Generally, according to the cultural standards in force, kindness or support must be repaid with kindness or support. In this context, the incumbent did not need to publicly vocalise his expectation that aid recipients would vote for him, because of the cultural values extant in Javanese society.

14 Original: [N]ek sing apik ki yo dipilih karena kita sudah diberi sarana dan prasarana, orang daerah sini rata-rata milih Pak $\mathrm{H}$, wonge apik tur ndak bermasalah (korupsi) 
The incumbent $(\mathrm{H})$ was considered friendly and polite. $\mathrm{He}$ often became directly involved in communities, and was considered very technology savvy (MRW, interview, January 18, 2017). The incumbent came to several events where zakat assistance was distributed, and at these events he would frequently speak. As stated by one informant, "The regent came when the assistance was distributed, although he only gave a speech and symbolically distributed some assistance" (JM, ibid). ${ }^{15}$

However, the incumbent's campaign also used testimonies from aid recipients. One short video uploaded to YouTube included the statement: "My name is SM, and I live in Nanggulan, Kulon Progo. Thank you, Pak H, for helping me build my house. Don't forget to vote for No. 2, Pak H-T"; 16 at the bottom of this video is a disclaimer stating that it was not produced with money from the regional budget. This video, released in December 2016, was one means through which the incumbent attempted to promote his signature programme in the lead-up to the election.

In the 2017 election in Kulon Progo, the incumbent's programmatic political practice, particularly his involvement of Baznas in the election, had an effect on the number of votes received. Referring to James Scott's typology of voters and their relations with politicians (i.e. patrons), the cultural context and relations between voters and patrons must be considered.

\section{Conclusion}

A monopoly of power will ultimately produce a monopoly over resources in society. Incumbent regents, who have significant power and legitimacy, make use of various sectors, including zakat money, to ensure the success of their programmes. With this ready control, incumbents - as single fighters or as people with trusted

15 Original: Pak Bupati datang pada saat pembagian hanya memberikan sambutan dan pemberian secara simbolis saja.

16 Original: "Nami kulo S M, alamat kulo nanggulan Kulon Progo, maturnuwun Pak H sampun dibantu bedah rumah, ampun kesupen coblos no 2 Pak $\mathrm{H}-\mathrm{T}$. 
figures in control of resources - are able to readily distribute zakat money to promote their populist programmes, something intended to gather electoral support.

The preparing of instructions and recommendations, as well as the guaranteeing of access to potential regional resources, was used by incumbents' to promote their programmes. The exploitation of zakat, a religious and social form of financial assistance, was given legislative backing to ensure its legality, even though zakat money was clearly used for the incumbents' programmes and even campaigns through secretive social relations. This was intended to build networks through Baznas, increase incumbents' popularity through populist programmes meant to address issues of poverty as well as improve the quality of education, etc. Indeed, this received considerable support from constituents. In this context, incumbents benefited greatly from the opportunity to use zakat money furtively, without recipients knowing the true source of the money they receive.

Baznas, despite being a hidden broker, had a significant role in the distribution of zakat money, which was claimed to originate from the regional government. This contributed another story to the lengthy relationship between religion and politics, as manifested in the use of zakat. However, where Samantha May (2013) argued that the state's dominance in the collection and distribution of zakat faced significant resistance, this research has shown that said dominance has been well received by local communities. As such, a political benefit is implicit for those government officials tasked with managing zakat collection and distribution.

The emphasis on club good and public good in the programmatic politics of incumbents in Magelang and Kulon Progo was reinforced by their pre-paid and post-paid strategies for gaining the sympathy of voters. This was supported by the cultural construct of "repaying favours" which has remained strong in society. 


\section{References}

Aspinall, E. \& Sukmajati, M. (Eds.). (2015) Politik uang di Indonesia, patronase dan klientalisme pada pemilu legislatif 2014. Yogyakarta: Polgov UGM.

Buehler, M. (2008). The rise of Shari'a by laws in Indonesian districts: An indication for changing patterns of power accumulation an political corruption, South East Asia Research Journal, 16(2), 255-285.

Detiknews.com, (April, 17 2014).

Djani, L. (2013) Penggunaan dana publik untuk kampanye. Retrieved from http://www.kemitraan.or.id.

Effendy, B. (1998) Islam dan negara transformasi pemikiran dan praktik politik Islam di Indonesia. Jakarta: Paramadina.

Fauzia, A. (2016), Filantropi Islam sejarah masyarakat sipil dan negara di Indonesia. Yogyakarta: Gading.

Jawa Pos, Radar Kedu, 2016

Latief, H. (2013). The politics of benevolence: Political patronage of partybased charitable organizations in contemporary Indonesian Islam, Al jami'ah; Journal of Islamic Studies, 51(2). doi:http://dx.doi. org/10.14421/ajis.2013.512.337-363

May, S. (2013). Political piety: The politicization of zakat, Middle East Critique Journal, 22(2), 149-164.

Schedler, A. \& Schaffer, F.C. (2007). What is vote buying?. In Frederic Charles Schaffer (ed.). Elections for Sale: The Causes and Consequences of Vote Buying. Manila: Ateneo de Manila University Press.

Stokes, S.C. (2007). Is vote buying undemocratic? In Frederic Charles Schaffer (ed.), Elections for Sale: The Causes and Consequences of Vote Buying. Manila: Ateneo De Manila University Press.

Triantini, Z.E., with Hartatik, E. (n.d.) Efektifitas program dana zakat sebagai pengentas kemiskinan di Jawa Tengah, Jawa Timur, dan Daerah Istimewa Yogyakarta.

Wahid, M., \& Alim, H. (Eds.) (2016), Jihad Nahdlatul Ulama melawan korupsi, Jakarta: Lakspedam NU. 